\title{
Mast Cell Chymase Potentiates Histamine-induced Wheal Formation in the Skin of Ragweed-allergic Dogs
}

\author{
Israel Rubinstein, Jay A. Nadel,** Paul D. Graf, and George H. Caughey* \\ Cardiovascular Research Institute and the Departments of ${ }^{*}$ Medicine and ${ }^{\ddagger}$ Physiology, \\ University of California, San Francisco, California 94143
}

\begin{abstract}
Skin mast cells release the neutral protease chymase along with histamine during degranulation. To test the hypothesis that chymase modulates histamine-induced plasma extravasation, we measured wheal formation following intradermal injection of purified mast cell chymase and histamine into the skin of ragweed-allergic dogs. We found that chymase greatly augments histamine-induced wheal formation. The magnitude of the potentiating effect increases with increasing doses of chymase and becomes maximal $\sim 30$ min after administration. Injection of chymase without histamine does not evoke wheal formation. The chymase potentiation of histamine-induced skin responses is prevented completely by pretreatment with the $\mathrm{H}_{1}$-receptor antagonist pyrilamine, and is prevented by inactivation of chymase with soybean trypsin inhibitor, suggesting that both histamine and preserved catalytic activity are required for the effects of chymase. To examine the effects of histamine and chymase released in situ in further experiments, we measured wheal size following local degranulation of mast cells by intradermal injection of ragweed antigen or compound 48/80. We found that pretreatment with either soybean trypsin inhibitor or pyrilamine markedly reduces ragweed antigen- or 48/80-induced wheal formation, supporting the results obtained by injection of exogenous chymase and histamine. These findings suggest a novel and important proinflammatory role for chymase in modulating the effects of histamine on vascular permeability during mast cell activation. (J. Clin. Invest. 1990. 86:555-559.) Key words: protease • immediate hypersensitivity $\bullet$ vascular permeability
\end{abstract}

\section{Introduction}

Mast cells are abundant in dog skin (1). When stimulated, they release mediators that participate in local allergic and inflammatory reactions (2). Histamine, the best known and characterized of preformed mast cell mediators, provokes a rapid increase in plasma extravasation in the skin when released during mast cell degranulation (3). Dog mast cell secretory granules also release extracellularly active neutral proteases,

Dr. Rubinstein's current address is the Department of Internal Medicine, University of Nebraska Medical Center, 42nd and Dewey Avenue, Omaha, NE 68105-1065.

Address correspondence and reprint requests to Dr. Caughey, Cardiovascular Research Institute, University of California, San Francisco, CA 94143-0911.

Received for publication 17 January 1990 and in revised form 4 April 1990.

J. Clin. Invest.

(c) The American Society for Clinical Investigation, Inc. 0021-9738/90/08/0555/05 \$2.00

Volume 86, August 1990, 555-559 including the chymotrypsin-like enzyme chymase $(4,5)$, which has a potential for degrading elements of connective tissue (6-9) and for causing inflammation in the skin; however, the role of chymase and other mast cell proteases relative to the role of histamine in causing changes in vascular permeability has not been clearly defined. In human skin, chymase is also a prominent constituent of mast cell granules $(10,11)$.

It was observed over three decades ago that a number of proteases differing in mechanistic class and substrate specificity produce itch when injected into human skin (12). Subsequent studies using rat mast cell chymase showed that injection into rat skin enhances local extravasation of albuminbound Evans blue (13) and that injection of rat chymase into human skin causes wheal, flare, and itch (14). Similar findings were noted when purified material containing chymase-like activity extracted from human skin was injected into the skin of humans and rabbits (15). The mechanism of action of chymase and other proteases in these studies was not determined, but in the case of chymase the effects were postulated to be mediated through histamine, because chymase-induced increases in vascular permeability were inhibited by histamine receptor antagonists (15) and were reduced by prior depletion of mast cell preformed mediators with compound 48/80 (14).

We hypothesized that mast cell chymase modulates changes in cutaneous vascular permeability provoked by mast cell histamine. To test this hypothesis, we investigated whether highly purified dog mast cell chymase injected intradermally alters histamine-induced plasma extravasation in the skin of ragweed-allergic dogs. We then tested the effects of chymase inhibition and histamine receptor blockade on wheal size following degranulation of skin mast cells in situ with compound $48 / 80$ and with ragweed antigen. The results suggest that chymase modulates the vasoactive effects of histamine in the skin.

\section{Methods}

Allergic dogs. The experimental protocol followed the published "Guiding Principles in the Care and Use of Animals" of the Council of the American Physiological Society and was approved by the Committee on Animal Care of the University of California, San Francisco. Study animals were chosen from a colony of allergic dogs that had undergone an immunization program that has been described previously (16). In brief, the 15 dogs used in this study were immunized within a month of birth with live attenuated distemper virus (Pittman-Moore, Washington Crossing, NJ) followed by short ragweed and mixed grass pollen extracts (Hollister-Steir, Spokane, WA); subsequently, the dogs were given yearly boosters of live distemper virus and bimonthly injections of short ragweed and mixed grass pollen extracts. These dogs maintain a high degree of circulating specific IgE-antibodies to both ragweed and mixed grass pollens and have been shown previously to exhibit cutaneous allergic responses similar to those of atopic humans $(2,3)$.

Purification of chymase. Dog mast cell chymase was obtained from "BR" mastocytoma cells originally derived from cells of a dog skin 
mastocytoma and established subsequently as a stable line passaged serially as subcutaneous nodules in athymic mice $(5,17)$. The purification of dog chymase, which is released from BR mastocytoma cells in a soluble and active form along with histamine (5), has been described previously (4). Briefly, chymase was extracted at high ionic strength from mastocytoma homogenates and separated from mast cell tryptase by gel filtration. Chymase was purified further by hydrophobic interaction and cation exchange chromatography. The substrate preferences and kinetics of substrate hydrolysis of dog mastocytoma chymase (4) appear to be very similar to those of the chymase purified from dog skin (18). The amino acid sequence of dog chymase deduced from cDNA obtained from a dog cDNA library suggests substantial structural similarities between dog and rodent chymases (19).

Wheal formation in response to exogenous chymase and histamine. The dogs $(16-23 \mathrm{~kg})$ used in this study were anesthetized by intravenous administration of sodium pentobarbital $(30 \mathrm{mg} / \mathrm{kg})$ and their abdominal skin was shaved with an electric clipper. The dogs were placed supine on a warming pad kept at $37^{\circ} \mathrm{C}$. The agents studied were made up in $100 \mu \mathrm{l}$ of sterile isotonic saline and injected intradermally. The tip of the hypodermic needle was inserted 1-2 mm into the skin at an angle almost parallel to the skin surface to limit the injection site to the most superficial layers, and the needle was held in place for $\sim 5 \mathrm{~s}$ after each injection to avoid back flow of the injected material along the needle track. Plasma extravasation in the skin was quantified by outlining the contours of each wheal with a marker pen on a transparent polypropylene sheet placed over the site of wheal formation 5,20 , and $30 \mathrm{~min}$ after injection. Because the wheal configuration was roughly circular, the largest diameter and the diameter at a right angle were measured and their product was used as the wheal area in the skin. The wheal area was corrected for contribution of the vehicle by subtracting the wheal area produced by control injections of vehicle alone. The effect of exogenously administered dog mast cell chymase on histamine-induced changes in vascular permeability in atopic dog skin was studied in two ways. In one series of experiments, plasma extravasation was measured after administration of $5 \mu \mathrm{g}$ of dog mast cell chymase injected intradermally with a $1-\mathrm{ml}$ syringe through a 28-gauge needle in the absence (control) or in the presence of increasing concentrations of histamine $\left(10^{-9}-10^{-5} \mathrm{M}\right)$. In a second group of experiments, we explored the relationship between the dose of chymase and the extent of plasma extravasation. Increasing concentrations of chymase $(0.05-5 \mu \mathrm{g})$ were injected together with a subthreshold concentration of histamine $\left(10^{-7} \mathrm{M}\right)$.

The effect of inhibition of dog mast cell chymase on histamine-induced plasma extravasation in atopic dog skin was examined by preincubating chymase $(5 \mu \mathrm{g})$ with soybean trypsin inhibitor (100 $\mu \mathrm{g} / \mathrm{ml}$ at $36^{\circ} \mathrm{C}$ for $10 \mathrm{~min}$ in a test tube) and then injecting the medium together with increasing concentrations of histamine $\left(10^{-9}-10^{-5} \mathrm{M}\right.$; final volume, $100 \mu \mathrm{l})$. Preincubation of chymase with this concentration of soybean trypsin inhibitor virtually abolished amidolytic activity using $N$-succinyl-L-Phe-Pro-Phe-4-nitroanilide as a chromogenic substrate (4), and secretagogue activity using airway submucosal gland serous cells (20). The effects of the $\mathrm{H}_{1}$-histamine receptor antagonist pyrilamine $\left(10^{-5} \mathrm{M}\right)$ injected intradermally $15 \mathrm{~min}$ before administration of chymase, and histamine on chymase $(5 \mu \mathrm{g})$ potentiation of histamine-induced wheal formation in atopic dog skin were studied using increasing concentrations of histamine $\left(10^{-9}-10^{-5} \mathrm{M}\right)$.

Wheal formation in response to compound $48 / 80$ and ragweed antigen. To examine the effects of chymase and histamine released endogenously from cutaneous mast cells, wheal formation was evaluated following mast cell degranulation with compound $48 / 80$ or ragweed antigen. To establish the relationship between wheal size and the concentration of the injected stimulus, increasing concentrations of compound $48 / 80$ ranging from 10 to $500 \mu \mathrm{g}$ or dilutions of ragweed extract ranging from $1: 10^{5}$ to $1: 10^{2}$ were injected $(100 \mu l)$ into the abdominal dermis of anesthetized ragweed-allergic dogs. Wheal size $30 \mathrm{~min}$ after injection was determined as described above. To examine the contribution to wheal size of endogenously released chymase, soybean trypsin inhibitor $(10 \mu \mathrm{g})$ was injected intradermally $15 \mathrm{~min}$ before injection of compound $48 / 80$ or ragweed extract into the same site. To compare the effects of chymase inhibition with those of histamine receptor blockade, pyrilamine $\left(10^{-5} \mathrm{M}\right)$ or a mixture of soybean trypsin inhibitor $(10 \mu \mathrm{g})$ and pyrilamine $\left(10^{-5} \mathrm{M}\right)$ was injected $15 \mathrm{~min}$ before administration of compound $48 / 80$ or ragweed antigen. The volume of each preinjection and of each injection of compound $48 / 80$ or ragweed extract was $100 \mu \mathrm{l}$, using sterile isotonic saline as a diluent. Control injections were made using the antigen extract diluent (isotonic saline and $0.4 \%$ phenol) alone.

Reagents. Histamine diphosphate, pyrilamine, soybean trypsin inhibitor, and compound 48/80 were obtained from Sigma Chemical Co. (St. Louis, MO). Extract of pollen from short ragweed (Ambrosia artemisiifolia, antigen E: $520.5 \mathrm{U} / \mathrm{ml}$, dissolved by mixing $1: 10 \mathrm{wt} / \mathrm{vol}$ in isotonic saline with $0.4 \%$ phenol) and the diluent of the antigen extract were obtained from Hollister-Stier. Dog mastocytoma-derived chymase $(200 \mu \mathrm{g} / \mathrm{ml}$ in $0.3 \mathrm{M} \mathrm{NaCl})$, histamine, pyrilamine, and soybean trypsin inhibitor were diluted in sterile isotonic saline on the day of the experiment and stored at $4^{\circ} \mathrm{C}$ until used.

Data analysis. Data are expressed as mean \pm SE. Statistical analysis was performed using analysis of variance and Dunnett's test for multiple comparisons (21).

\section{Results}

Responses to exogenous histamine and chymase. Intradermal injection of histamine evoked wheal formation -in a concentration-dependent manner (Fig. 1). The threshold concentration of histamine that induced a significant increase in wheal size over baseline was $>10^{-7} \mathrm{M}$; a maximal response to histamine was not reached in the range of concentrations used $\left(10^{-9}-10^{-5} \mathrm{M}\right)$. When histamine was administered intradermally together with dog chymase $(5 \mu \mathrm{g})$, the concentration-response curve to histamine was shifted markedly to the left (Fig. $1 ; P<0.01)$. Intradermal administration of dog chymase alone did not evoke plasma extravasation. The potentiation by chymase of histamine-induced responses in the skin was completely inhibited by the $\mathrm{H}_{1}$-receptor antagonist pyrilamine $\left(10^{-5} \mathrm{M}\right)$ over a range of histamine concentrations from $10^{-9}$ to $10^{-5} \mathrm{M}(n=5$; data not shown). The increase in wheal size caused by intradermal administration of chymase $(5 \mu \mathrm{g})$ together with histamine $\left(10^{-9}-10^{-5} \mathrm{M}\right)$ was evident within $5 \mathrm{~min}$ and became maximal after 20-30 min (Fig. 2). After $30 \mathrm{~min}$, wheal formation due to the combination of chymase and histamine was significantly greater than that due to histamine without chymase $(n=7 ; P<0.01)$. Wheal responses at a fixed concentration of histamine $\left(10^{-7} \mathrm{M}\right)$ increased significantly

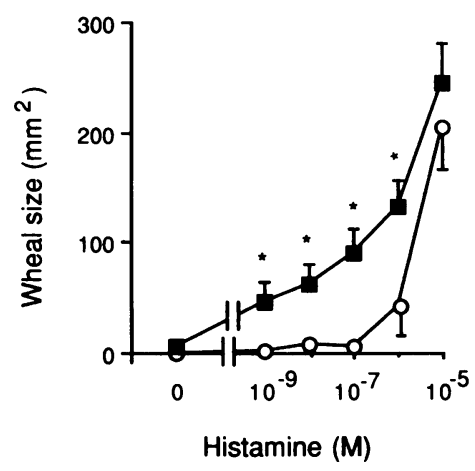

Figure 1. Effect of exogenous dog chymase $(5 \mu \mathrm{g})$ on concentration-response curve to histamine injected intradermally into ragweedallergic dog skin (seven dogs). Histamine-induced wheal size was measured in the presence $(\square)$ or absence (o) of chymase. Data shown are mean values $\pm \mathrm{SE}$. Differences in mean wheal size with $P$ $<0.05$ produced by the

combination of chymase and histamine compared to histamine alone are indicated by an asterisk. 


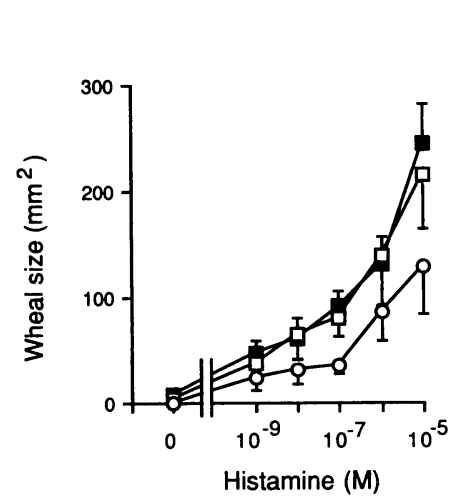

Figure 2. Time-dependence of wheal formation in response to exogenous chymase $(5 \mu \mathrm{g})$ and histamine $\left(10^{-9}-10^{-5} \mathrm{M}\right)$ injected intradermally into ragweed-allergic dog skin (seven dogs). Wheal size was measured after $5 \mathrm{~min}(\mathrm{O}), 20 \mathrm{~min}(\square)$, and $30 \mathrm{~min}(\mathbf{\square})$. Maximal responses at each concentration of histamine were seen in 20-30 min. Data shown are mean values $\pm \mathrm{SE}$.

with increasing concentrations of chymase (Fig. $3 ; n=7 ; P$ $<0.01)$.

To determine whether the active catalytic site of chymase is required for initiating the potentiating effect on histamine-induced wheal formation in the skin, dog chymase $(5 \mu \mathrm{g})$ was preincubated at $37^{\circ} \mathrm{C}$ for $10 \mathrm{~min}$ with the active site inhibitor soybean trypsin $(100 \mu \mathrm{g} / \mathrm{ml})$ in the test tube before injecting the medium together with increasing concentrations $\left(10^{-9}\right.$ $10^{-5} \mathrm{M}$ ) of histamine. The potentiation by chymase of histamine-induced responses in the skin was prevented by soybean trypsin inhibitor at all histamine concentrations used $(n=6 ; P$ $<0.001$; data not shown).

Responses to compound $48 / 80$ and to ragweed antigen. Injection of compound $48 / 80$ or ragweed antigen caused development of wheals whose size depended on the concentration of the mast cell degranulating agent (Figs. 4 and 5). Pretreatment with soybean trypsin inhibitor to inhibit chymase decreased wheal size significantly $(P<0.01)$ in response to injection of all concentrations of compound $48 / 80$ or ragweed antigen. Further reduction in wheal size was seen after pretreatment with either pyrilamine or the combination of soybean trypsin inhibitor and pyrilamine (Figs. 4 and 5). The effects of pyrilamine alone were not different from those of pyrilamine plus soybean trypsin inhibitor.

\section{Discussion}

The marked potentiation of histamine-induced plasma extravasation by mast cell chymase that we found in the skin of ragweed-sensitized dogs suggests a novel and important inter-

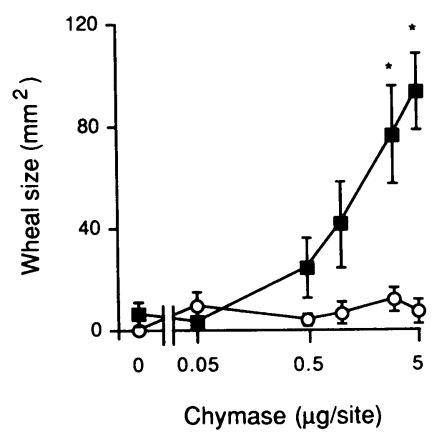

Figure 3. Effect of concentration of exogenous dog chymase on histamine injected intradermally into ragweed-allergic dog skin (seven dogs). Chymase alone (O) injected in amounts of up to $5 \mu \mathrm{g} / \mathrm{site}$ did not cause wheal formation, whereas the injection of chymase in combination with a subthreshold concentration of histamine $\left(10^{-7} \mathrm{M}\right)(\mathbf{a})$ caused a concentration-dependent increase in wheal size. Data shown are mean values \pm SE. Differences in mean wheal size with $P<0.05$ produced by the combination of chymase and histamine compared to chymase alone are indicated by an asterisk.

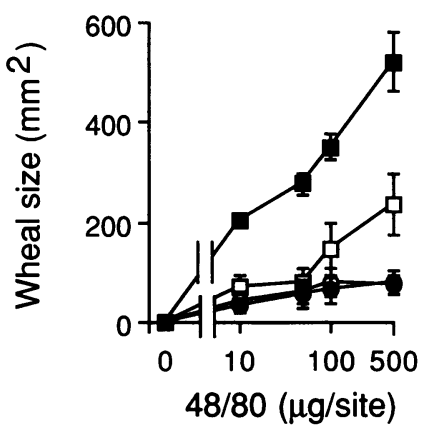

Figure 4. Effects in vivo of chymase inhibition and histamine receptor blockade on compound 48/80-induced wheal formation in allergic dog skin (four dogs). Wheal formation in response to injection of compound $48 / 80$ alone ( $(\bullet)$ increases with increasing concentrations of compound $48 / 80$. Wheal formation in response to compound $48 / 80$ is reduced at sites pretreated with soy-

bean trypsin inhibitor (ㅁ) (an inhibitor of chymase), with pyrilamine (O) (an $\mathrm{H}_{1}$ histamine receptor antagonist), or with the combination of soybean trypsin inhibitor and pyrilamine $(\bullet)$. Data shown are mean values $\pm \mathrm{SE}$.

action between two of the major preformed mediators of mast cell secretory granules. The possibility that mast cell chymase augments histamine effects is particularly interesting because mast cell chymase and histamine are released together from the same mast cell granules (5). Furthermore, unlike many serine proteases that are stored as inactive zymogens, dog chymase appears to be packaged in its mature form within granules, so it is fully active upon release with histamine $(5,22)$. Unlike rat connective tissue mast cell chymase (rat chymase I), which is thought to remain near the site of exocytosis as an active but insoluble component of an extruded granule from which histamine dissociates (23), dog chymase appears to be fully soluble upon release (5). Therefore, both chymase and histamine in dog skin may be able to reach the same cellular targets when released from mast cells in the skin as when injected exogenously as soluble, purified mediators in our experiments. The potentiating effect of chymase on histamineinduced wheal formation provides a potential explanation for the observed increase in responsiveness to exogenously administered histamine following the injection of antigen into the skin of ragweed-allergic dogs (3).

In previous studies of various preparations of mast cell chymase injected into rat, rabbit, and human skin (13-15), the observed responses (e.g., increased vascular permeability and itch) could have been attributed to chymase-stimulated release of histamine from resident skin mast cells. Indeed, studies carried out in vitro suggest that mast cell chymase may be able

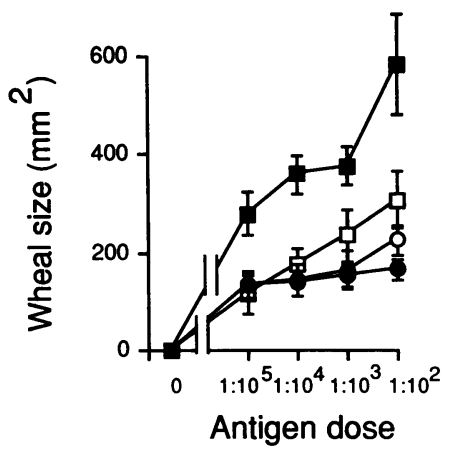

Figure 5. Effects in vivo of chymase inhibition and histamine receptor blockade on ragweed antigen-induced wheal formation in ragweedallergic dogs (five dogs). Wheal formation in response to injection of ragweed antigen alone ( $\boldsymbol{\square})$ increases with increasing doses of antigen. Wheal formation in response to antigen is reduced at sites pretreated with soybean trypsin inhibitor ( $\square$ ) (an inhibitor of chymase), with pyrilamine (O) (an $\mathrm{H}_{1}$ histamine receptor antagonist), or with the combination of soybean trypsin inhibitor and pyrilamine (๑). Data shown are mean values $\pm \mathrm{SE}$. 
to degranulate mast cells (24) and airway submucosal gland serous cells (20), although the significance of these observations in vivo remains to be shown. However, this potential secretagogue effect of chymase cannot be invoked as an explanation of the findings in the current study because exogenously administered chymase, in the range of concentrations used, produces no increase in wheal size in the absence of histamine. The finding that the chymase-augmented wheal formation in response to histamine is entirely prevented by $\mathrm{H}_{1}$-receptor blockade, further underscores the histamine dependence of this effect of chymase.

The actions of chymase identified in this study are likely to be mediated by hydrolysis of molecular targets in the dermis because potentiation of plasma extravasation is abolished by an active site inhibitor of chymase. However, the molecular and cellular targets of chymase responsible for these effects of chymase remain to be determined. One potential target is intercellular matrix, whose elements, including collagen, proteoglycans, and other proteins (if degraded by chymase) may present fewer impediments to the free flow of extravasated fluid, and result in exaggerated wheal formation. Such postulated actions of chymase are consistent with the known effects of the enzyme on components of connective tissue (6-9). Alternatively, chymase may inactivate histamine degrading enzymes, thereby increasing levels or delaying the disappearance of histamine, with a resulting enhancement of histamine effects on vascular permeability; or chymase may cause arteriolar vasodilatation in the skin, thereby increasing blood flow and the potential for extravasation of plasma from postcapillary venules.

The concentration of mast cell chymase in dog skin is not known. Therefore, it is difficult to predict with certainty whether the concentrations of chymase administered exogenously in this study fall within a range that is pathophysiologically significant. However, there are $2-3 \times 10^{6}$ mast cells $/ \mathrm{cm}^{3}$ in ragweed-sensitized dog skin $(1,2)$. All of these mast cells exhibit chloroacetate esterase activity, which is thought to be due to chymase (22). If one assumes that dog mast cells, like those of human skin, contain $\sim 10 \mathrm{pg}$ of chymase/cell, then dog skin contains $20-30 \mu \mathrm{g}$ of chymase $/ \mathrm{cm}^{3}$. Concentrations of chymase in the immediate vicinity of a degranulating mast cell could be considerably higher. Furthermore, in certain pathologic skin disorders such as scleroderma (25), the concentrations of mast cells in the dermis may be greatly increased. Therefore, the concentrations of chymase used in this study may be matched or exceeded in tissue microenvironments during mast cell activation and exocytosis. This conclusion is supported strongly by the finding that wheal formation, following exogenous release of mast cell histamine and chymase by compound $48 / 80$ or antigen, is reduced by prior injection of a chymase inhibitor. One might also speculate that mast cell tryptase, the other major neutral endoprotease packaged with histamine and chymase in dog mast cell granules (5, 22,26 ), has a role in modulating histamine-induced wheal formation. Dog tryptase has been found to augment histamine-induced smooth muscle contraction in dog bronchi (27). However, unlike dog chymase, dog tryptase is not inactivated by soybean trypsin inhibitor (26). Therefore, the results of the studies with compound $48 / 80$ and ragweed antigen indicate that any potentiating effects of mast cell tryptase are unlikely to be significant compared to those of chymase.
In conclusion, highly purified dog mast cell chymase exhibits marked concentration-dependent potentiation of histamine-induced wheal formation in ragweed-allergic dog skin. The chymase-induced augmentation of histamine responses is abolished by pretreatment with an $\mathrm{H}_{1}$-receptor antagonist and requires chymase catalytic activity. Inhibition of chymase released from compound 48/80- or ragweed antigen-stimulated mast cells in situ substantially reduces wheal formation. These findings suggest a previously unrecognized role for mast cell chymase in modulating the effects of histamine on vascular permeability.

\section{Acknowledgments}

We thank Dr. Oscar L. Frick for his invaluable assistance in providing the dogs for these studies.

This work was supported by grants AI-15233, HL-24136, and HL-01736 from the National Institutes of Health. Dr. Caughey is an RJR Nabisco Research Scholar.

\section{References}

1. Becker, A. B., K. F. Chung, D. M. McDonald, S. C. Lazarus, O. L. Frick, and W. M. Gold. 1985. Mast cell heterogeneity in dog skin. Anat. Rec. 213:477-480.

2. Becker, A. B., K. F. Chung, D. M. McDonald, S. C. Lazarus, and W. M. Gold. 1986. Cutaneous mast cell heterogeneity: response to antigen in atopic dogs. J. Allergy Clin. Immunol. 78:937-942.

3. Becker, A. B., K. F. Chung, D. M. McDonald, O. L. Frick, and W. M. Gold. 1988. Cutaneous allergic response in atopic dogs: relationship of cellular and histamine responses. J. Allergy Clin. Immunol. 81:441-448.

4. Caughey, G. H., N. F. Viro, S. C. Lazarus, and J. A. Nadel. 1988. Purification and characterization of dog mastocytoma chymase: identification of an octapeptide conserved in chymotryptic leukocyte proteases. Biochim. Biophys. Acta. 952:142-149.

5. Caughey, G. H., S. C. Lazarus, N. F. Viro, W. M. Gold, and J. A. Nadel. 1988. Tryptase and chymase: comparison of extraction and release in two dog mastocytoma lines. Immunology. 63:339-344.

6. Briggaman, R. A., N. M. Schechter, J. Fraki, and G. S. Lazarus. 1984. Degradation of the epidermal-dermal junction by proteolytic enzymes from human skin and human polymorphonuclear leukocytes. J. Exp. Med. 160:1027-1042.

7. Seppa, H., K. Vaananen, and K. Korhonen. 1979. Effect of mast cell chymase of rat skin on intercellular matrix: a histochemical study. Acta Histochem. 64:64-70.

8. Sage, H., R. G. Bornstein, and P. Bornstein. 1979. Structural studies of human type IV collagen. J. Biol. Chem. 254:9893-9900.

9. Vartio, T., H. Seppa, and A. Vaheri. 1981. Susceptibility of soluble and matrix fibronectins to degradation by tissue proteinases, mast cell chymase and cathepsin G. J. Biol. Chem. 256:471-477.

10. Sayama, S., R. V. Iozzo, G. S. Lazarus, and N. M. Schechter. 1987. Human skin chymotrypsin-like proteinase chymase: subcellular localization to mast cell granules and interaction with heparin and other glycosaminoglycans. J. Biol. Chem. 263:6808-6815.

11. Irani, A. A., N. M. Schechter, S. S. Craig, G. DeBlois, and L. B. Schwartz. 1986. Two types of human mast cells that have distinct neutral protease compositions. Proc. Natl. Acad. Sci. USA 83:44644468.

12. Arthur, R. P., and W. B. Shelley. 1955. The role of proteolytic enzymes in the production of pruritus in man. J. Invest. Dermatol. 25:341-346.

13. Seppa, H. 1980. The role of chymotrypsin-like protease of rat mast cells in inflammatory vasopermeability and fibrinolysis. Inflammation. 4:1-8. 
14. Hagermark, O., G. Rajka, and U. Berqvist. 1972. Experimental itch in human skin elicited by rat mast cell chymase. Acta Dermatovenereol. 52:125-128.

15. Fraki, J. E. 1977. Human skin proteases: effect of separated proteases on vascular permeability and leukocyte emigration in skin. Acta Dermato-venereol. 57:393-398.

16. Frick, O. L., and D. L. Brooks. 1983. Immunoglobulin E antibodies to pollens augmented in dogs by virus vaccines. Am. J. Vet. Res. 44:440-445.

17. Lazarus, S. C., R. DeVinney, L. J. McCabe, W. E. Finkbeiner, D. J. Elias, and W. M. Gold. 1986. Isolated canine mastocytoma cells: propagation and characterization of two cell lines. Am. J. Physiol. 251:C935-C944.

18. Powers, J. C., T. Tanaka, J. W. Harper, Y. Minematsu, L. Barker, D. Lincoln, K. V. Crumley, J. E. Fraki, N. M. Schechter, G. G. Lazarus, K. Nakajima, K. Nakashino, H. Neurath, and R. G. Woodbury. 1985. Mammalian chymotrypsin-like enzymes: comparative reactivities of rat mast cell proteases, human and dog skin chymases, and human cathepsin $G$ with peptide 4-nitroanilide substrates and with peptide chloromethyl ketone and sulfonyl fluoride inhibitors. Biochemistry. 24:2048-2058.

19. Caughey, G. H., W. W. Raymond, and P. Vanderslice. 1990. Dog mast cell chymase: molecular cloning and characterization. Biochemistry. 29:5166-5171.

20. Sommerhoff, C. P., G. H. Caughey, W. E. Finkbeiner, S. C. Lazarus, C. B. Basbaum, and J. A. Nadel. 1989. Mast cell chymase: a potent secretagogue for airway gland serous cells. J. Immunol. 142:2450-2456.

21. Zar, J. H. 1974. Biostatistical Analysis. Prentice-Hall, Englewood Cliffs, NJ. 620 pp.

22. Caughey, G. H., N. F. Viro, L. D. Calonico, D. M. McDonald, S. C. Lazarus, and W. M. Gold. 1988. Chymase and tryptase in dog mastocytoma cells: asynchronous expression as revealed by enzyme cytochemical staining. J. Histochem. Cytochem. 36:1053-1060.

23. Schwartz, L. B., C. Riedel, J. P. Caulfield, S. I. Wasserman, and K. F. Austen. 1981. Cell association of complexes of chymase, heparin proteoglycan, and protein after degranulation by rat mast cells. $J$. Immunol. 126:2071-2078.

24. Schick, B., K. F. Austen, and L. B. Schwartz. 1984. Activation of rat serosal mast cells by chymase, an endogenous secretory granule protease. J. Immunol. 132:2571-2577.

25. Hawkins, R. A., H. N. Claman, R. A. F. Clark, and J. C. Steigerwald. 1985. Increased dermal mast cell populations in progressive systemic sclerosis: a link in chronic fibrosis? Ann. Intern. Med. 102:182-186.

26. Caughey, G. H., N. F. Viro, J. Ramachandran, S. C. Lazarus, D. B. Borson, and J. A. Nadel. 1987. Dog mastocytoma tryptase: affinity purification, characterization and amino-terminal sequence. Arch. Biochem. Biophys. 258:555-563.

27. Sekizawa, K., G. H. Caughey, S. C. Lazarus, W. M. Gold, and J. A. Nadel. 1989. Mast cell tryptase causes airway smooth muscle hyperresponsiveness in dogs. J. Clin. Invest. 83:175-179. 